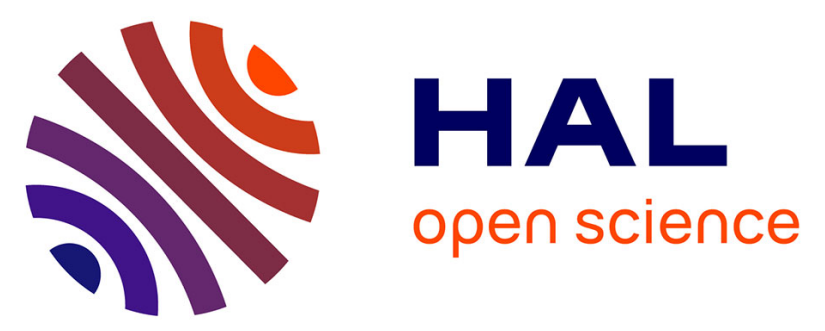

\title{
Evidence of circulation of West Nile virus in Culex pipiens mosquitoes and horses in Morocco
}

Najlaa Assaid, Laurence Mousson, Sara Moutailler, Soukaina Arich, Khadija

Akarid, Maëlle Monier, Cécile Beck, Sylvie Lecollinet, Anna-Bella Failloux, M'Hammed Sarih

\section{To cite this version:}

Najlaa Assaid, Laurence Mousson, Sara Moutailler, Soukaina Arich, Khadija Akarid, et al.. Evidence of circulation of West Nile virus in Culex pipiens mosquitoes and horses in Morocco. Biochimica et Biophysica Acta:Biomembranes, 2020, 205, 10.1016/j.actatropica.2020.105414 . pasteur-02495904

\section{HAL Id: pasteur-02495904}

https://hal-pasteur.archives-ouvertes.fr/pasteur-02495904

Submitted on 10 Mar 2020

HAL is a multi-disciplinary open access archive for the deposit and dissemination of scientific research documents, whether they are published or not. The documents may come from teaching and research institutions in France or abroad, or from public or private research centers.
L'archive ouverte pluridisciplinaire HAL, est destinée au dépôt et à la diffusion de documents scientifiques de niveau recherche, publiés ou non, émanant des établissements d'enseignement et de recherche français ou étrangers, des laboratoires publics ou privés.

\section{(ㅇ)(1) $\$$}

Distributed under a Creative Commons Attribution - NonCommerciall 4.0 International 


\section{Evidence of circulation of West Nile virus in Culex pipiens 2 mosquitoes and horses in Morocco}

3

4 Najlaa Assaid ${ }^{1,2}$, Laurence Mousson ${ }^{3}$, Sara Moutailler ${ }^{4}$, Soukaina Arich ${ }^{1}$, Khadija Akarid ${ }^{2}$, 5 Maëlle Monier ${ }^{5}$, Cécile Beck ${ }^{5}$, Sylvie Lecollinet ${ }^{5}$, Anna-Bella Failloux ${ }^{3}$ II, M'hammed Sarih $6{ }^{1} \mathbb{I}^{*}$.

7

8

${ }^{1}$ Institut Pasteur du Maroc, Service de Parasitologie et des Maladies Vectorielles, Place Louis Pasteur, Casablanca 20360, Morocco

${ }^{2}$ Molecular Genetics and Immunophysiopathology Research Team, Health and Environment Laboratory, Aïn Chock Faculty of Sciences, University of Hassan II Casablanca (UH2C), Casablanca, Morocco.

${ }^{3}$ Institut Pasteur, Department of Virology, Arboviruses and Insect Vectors, 25-28 rue du Docteur Roux, Paris 75724, France

${ }^{4}$ UMR BIPAR, Animal Health Laboratory, INRAE, ANSES, Ecole Nationale Vétérinaire d'Alfort, Université Paris-Est, Maisons-Alfort, France.

${ }^{5}$ UMR1161 Virologie, INRAE, ANSES, Ecole Nationale Vétérinaire d'Alfort, Université Paris-Est, Maisons-Alfort, France

ITThese authors contributed equally to this work

*Corresponding author:

E-mail: mhammed.sarih@pasteur.ma (MS)

Emails:

Najlaa Assaid : najlaa.essaid@gmail.com

Laurence Mousson : laurence.mousson@pasteur.fr

Sara Moutailler : $\underline{\text { sara.moutailler@anses.fr }}$

Soukaina Arich : arichsoukaina@gmail.com

Khadija Akarid : kakarid@yahoo.fr

Cecile Beck : cecile.beck@anses.fr

Maëlle Monier : maelle.monier@anses.fr

Sylvie Lecollinet : sylvie.lecollinet@anses.fr

Anna-Bella Failloux : anna-bella.failloux@pasteur.fr

M'hammed Sarih : mhammed.sarih@pasteur.ma 


\section{Abstract}

West Nile virus (WNV) is one of the most widely distributed mosquito-borne viruses in the world. In North Africa, it causes human cases of meningoencephalitis with fatalities in Algeria and in Tunisia, whereas only horses were affected in Morocco. The aims of this study were to detect WNV in mosquitoes and to determine seroprevalence of WNV in Moroccan horses by the detection of $\operatorname{IgG}$ antibodies. A total of 1,455 mosquitoes belonging to four different species were grouped by collection site, date, and sex with 10 specimens per pool and tested for 38 arboviruses using a high-throughput chip based on the BioMark Dynamic array system. Out of 146 mosquito pools tested, one pool was positive for WNV. This positive pool was confirmed by real time RT-PCR. The serosurvey showed that $33.7 \%$ (31/92) of horses were positive for competitive enzyme-linked immunosorbent assay (cELISA) test. The flavivirus-sphere microsphere immnoassay (MIA) test, targeting three flaviviruses (WNV, Usutu virus (USUV) and Tick borne encephalitic virus (TBEV)) showed that 23 sera out of 31 were positive for WNV, two for USUV, two for USUV or WNV, and four for an undetermined flavivirus. Virus neutralization tests with USUV and WNV showed that 28 of 31 sera were positive for WNV and all sera were negative for USUV. This study reports, for the first time, the detection of WNV from Culex pipiens mosquitoes in Morocco and its circulation among horses. This highlights that the detection of arboviruses in mosquitoes could serve as an early warning signal of a viral activity to prevent future outbreaks in animals and humans.

Keywords: Mosquito-borne-viruses; Culex pipiens; Horses; WNV; RT-PCR; Serological technics

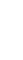
58 59 


\section{Introduction}

Arboviruses (Arthropod-borne viruses) circulate primarily within an enzootic cycle among wild animals, and spillover transmission to humans and domestic animals have been more frequently reported since two decades (Weaver and Reisen, 2010). Some viruses such as dengue (DENV), chikungunya (CHIKV) and Zika, do not longer need to amplify in animal species to trigger urban epidemic cycles and produce extensive epidemics (Weaver et al., 2018). Factors contributing to these changes are diverse but all point out the preponderant role of human activities in creating ecological niches suitable to vector-borne pathogens, worsened by climate changes offering larger regions suitable to mosquito development (Sutherst, 2004). Among these arboviruses, West Nile virus (WNV; Flaviviridae, Flavivirus) is maintained in nature in an enzootic transmission cycle between birds and Culex mosquitoes. It also infects humans and other animals causing a serious disease and death (Hayes, 2001; Murgue et al., 2001). Birds are considered to be the most important hosts of WNV because they can develop a sufficient viremia to infect mosquitoes after a blood supply (Komar et al., 2003). Humans and horses develop weak and short-term viremia and are considered as dead end hosts (Bowen and Nemeth, 2007). Since its discovery in 1937 in Uganda (Smithburn, 1942), WNV has circulated in Africa mainly associated with mild symptoms (Benjelloun et al., 2016; Sule et al., 2018). The first outbreak describing neuroinvasive symptoms in humans was reported in Israel in 1951 (Murgue et al., 2001). After a silence of more than 30 years, a new emergence, in Romania in 1996 then in Italy and in France respectively in 1998 and in 2000. Since 2004, new strain of the line2 circulates in Europe (Lecollinet et al., 2020). In 1999, WNV was first detected in the Unites States, in New York (Nash et al., 2001) and then spread to the West coast, to Canada and to Central and South America (Banet-Noach et al., 2003; Charrel et al., 2003).

Currently, WNV is present in Africa, the Middle East, Europe, Asia, Australia and America and has become the most widely distributed of the encephalitic flaviviruses (Chancey et al., 2015). It possesses one of the highest potentials for re-emergence in North Africa; WNV circulates actively in the region based on two lines of evidence: (i) repeated reports of WNV outbreaks in this region and (ii) the vector $C x$. pipiens widely present. WNV has been circulating for a very long time in the Mediterranean region (Murgue et al., 2001) affecting mainly humans and horses (Benjelloun et al., 2016; Johnson et al., 2018; Papa, 2019). In Morocco, several outbreaks of WNV have been reported: (i) in 1996 with 94 equine cases including 42 deaths and only one human case (El Harrack et al., 1997; Tber Abdelhaq, 1996), 
(ii) in September and October of 2003 when WNV circulated among horses in Kenitra (Schuffenecker et al., 2005), (iii) in 2010 in horses (World Animal Health Information Database, 2010 ; Benjelloun et al., 2017; Durand et al., 2016; El Rhaffouli et al., 2013). The two strains of WNV (outbreaks in 1996 and 2003) belonged to clade 1a of lineage 1 (schuffenecker et al., 2005). The principal vector of WNV in Europe, Northern USA and North Africa is Culex pipiens which is the most widespread vector in temperate regions including North Africa (Amraoui et al., 2012b; Romo et al., 2018). Moreover, two coexisting Culex pipiens forms (pipiens and molestus) are distinguished in temperate areas and correspond to different behavioral, physiological and genetic forms (Harbach, 2012). The form pipiens is ornithophilic while molestus bites humans and other mammals (Fonseca et al., 2004). These two forms have been proven to hybridize in some regions such as the United States (Fonseca et al., 2004), South Europe (Gomes et al., 2009) and North Africa (Amraoui et al., 2012a; Krida et al., 2015). Hybrids show intermediate trophic preferences assigning them the role of bridge vector for a viral transmission from animals to humans (Fonseca et al., 2004). Targeted surveillance for WNV within mosquito populations offers an opportunity to detect virus prior to the emergence of disease in equine species or human populations (Calzolari et al., 2012). To date, no virological data concerning WNV in mosquitoes from Morocco are available. The aims of this study are: (i) Evaluation of the circulation of mosquito-borne arboviruses in Morocco using a new high-throughput tool based on the BioMark TM Dynamic matrix system capable of screening a large panel of arboviruses in a single experiment. (ii) Detection of WNV past circulation in equids through the confirmation of anti-WNV antibodies in horse serum samples by three serological techniques: cELISA, MIA and microneutralization test (MNT).

\section{Materials and methods}

\subsection{Study sites}

The three regions selected for the study are: (i) Mohammedia, a large city located on the coast of the Atlantic Ocean, at $24 \mathrm{~km}$ northeast from Casablanca $\left(33^{\circ} 40^{\prime} 25.3^{\prime \prime} \mathrm{N} 7^{\circ} 26^{\prime} 42.5^{\prime \prime} \mathrm{W}\right)$, where WNV cases were reported in horses in 2010; (ii) Moulay Bouselham $34^{\circ} 52^{\prime} 28.7^{\prime \prime} 6^{\circ} 17^{\prime} 14.5^{\prime \prime} \mathrm{W}$, where WNV cases were reported in horses in 2010 and (iii) Tanger $35^{\circ} 46^{\prime} 44.3 \mathrm{~N}^{\circ} 50^{\prime} 50.1 \mathrm{~W}$ located on the North of Morocco, where WNV cases were 
reported in horses in 1996". Sites of mosquito captures were identified based on records of past circulation areas for WNV (at a period corresponding to a season of high potential transmission risk with high densities of mosquitoes, presence of migratory birds, case reports of meningoencephalitis ...).

\subsection{Mosquito collection}

Adult mosquito collections were conducted over four consecutive nights in September and October 2018 using six CDC light traps (Communicable Disease Centers of Atlanta, USA) supplemented with dry ice as a source of $\mathrm{CO} 2$ (from 7:00 pm to 7:00 am) in three regions (Figure 1). The traps were placed approximately 1.5 meters above ground. Traps were dispersed inside houses and near stables and lakes. Live mosquitoes were transported in cages to the laboratory to be identified using identification keys (Brunhes et al., 2000). The identification was carried out on living mosquitoes asleep by the cold on a freeze pack.

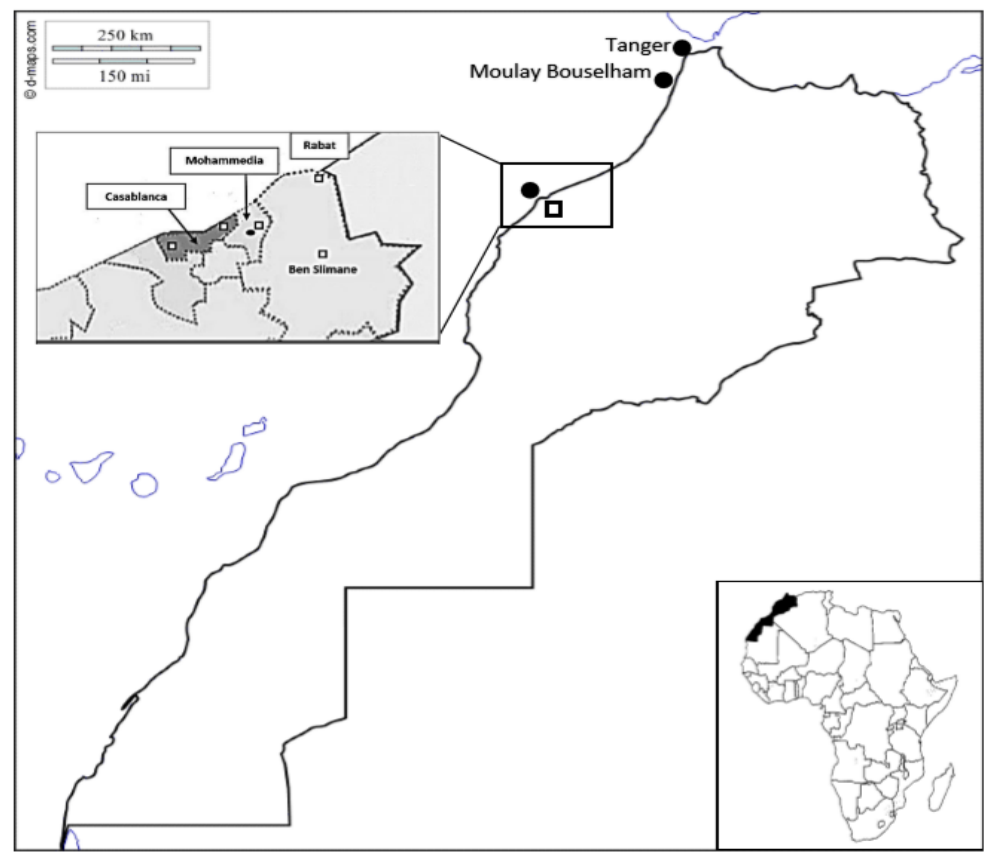

Fig.1. Map of the study area showing the location of mosquito collection cities ( $)$ (Tanger, Moulay Bouselham, Mohammedia) and horse serum collection sites ( $\square$ ) (Casablanca, Mohammedia, Benslimane).

\subsection{Mosquito dissection and RNA extraction}

After morphological identification, mosquitoes were dissected on a freeze pack to isolate the abdomen from the remaining parts of the body. Abdomens of the same species were grouped 
in pools of 10 individuals and the rest of mosquito bodies were stored individually at $-80^{\circ} \mathrm{C}$ until RNA extraction.

Total RNAs were extracted from each pool using Nucleospin RNA kit according to the manufacturer's instructions. Pools were grinded in $350 \mu \mathrm{L}$ Lysis Buffer and $3.5 \mu \mathrm{L} \beta$ mercaptoethanol using piston stirrer. Total RNA per pool was eluted in $60 \mu \mathrm{L}$ of RNase free water and stored at $-80 \circ \mathrm{C}$ until use.

\subsection{Reverse Transcription and cDNA Pre-Amplification}

RNAs were transcribed to cDNA by reverse transcription using the qScript cDNA Supermix kit according to the manufacturer's instructions (Quanta Biosciences, Beverly, USA). For cDNA pre-amplification, the Perfecta Preamp Supermix (Quanta Biosciences, Beverly, USA) was used according to the manufacturer's instructions. These two procedures were performed according to the protocols described by Moutailler et al., 2019.

\subsection{High-throughput real-time PCR system}

A high throughput epidemiological surveillance method based on a microfluidic system (Fluidigm, South San Francisco, CA, USA) was used according to the protocol described by Moutailler et al., 2019. This technic is more sensitive than real time PCR. This method allows to perform real-time PCR using 96.96 chips, resulting in 9216 individual reactions. The primer sequences / probe sets used in this study are available in Moutailler et al. 2019. A negative water control has been included for each chip. A positive control with cDNA (virus reference material) or DNA (Plasmid) was used. To determine if inhibitors could be present in the sample, DNA from the Escherichia coli strain EDL933 was added to each sample as an internal inhibition control, using gene-specific primers and probes E. coli eae (Nielsen \& Andersen, 2003). Data were acquired on the BioMarkTM real-time PCR system and analyzed using Fluidigm real-time PCR analysis software to obtain Ct values (Michelet and al., 2014).

\subsection{Real time PCR}

RNA from WNV positive mosquito pool was screened by real-time PCRs on a StepOne Instrument (Applied Biosystem, Thermo Fisher Scientific, Illkirch, France). Real-time RTPCR assay targeting a different segment of the WNV genome (5'UTR and part of the capsid gene) (Linke et al., 2007) was performed in a final volume of $25 \mu \mathrm{L}$ using $5 \mu \mathrm{L}$ of RNA and AgPath-ID ${ }^{\text {TM }}$ One-Step RT-PCR Reagents (Thermo Fisher Scientific, France) containing 
primers and probes at $400 \mathrm{nM}$ and $200 \mathrm{nM}$ respectively. Thermal cycling conditions were as follows: $45^{\circ} \mathrm{C}$ for 10 minutes, $95^{\circ} \mathrm{C}$ for $10 \mathrm{~min}, 45$ cycles at $95^{\circ} \mathrm{C}$ for $15 \mathrm{~s}$ and $60^{\circ} \mathrm{C}$ for $1 \mathrm{~min}$.

\subsection{Blood sampling and recovery of horse sera}

A total of 92 horses were sampled in five different equestrian clubs, located in the region of Casablanca-Mohammedia-Benslimane (area where was declared the last WNV epizootic in Morocco in 2010) (figure1). Horses sampled were more than 2 years old, male and female, and of different breeds; they showed no clinical signs associated with West Nile disease. Each blood sample was collected in dry tubes and transported at $+4^{\circ} \mathrm{C}$ to the laboratory where samples were centrifuged. The sera were aliquoted, separated and stored at $-20^{\circ} \mathrm{C}$ until use.

\subsection{Serological test}

\subsubsection{Competitive enzyme-linked immunosorbent assay (cELISA)}

The serological diagnosis was made using a cELISA test (ID Screen® West Nile Competition ELISA Kit, ID Vet, France) to give an indication of the presence or absence of anti-WNV antibodies in horses sera. Analysis and interpretation were performed according to the manufacturer's instructions. The optical density was observed and the $\mathrm{S} / \mathrm{N}$ ratio (optical density of the sample / optical density of the negative control *100) was calculated. Samples with a $\mathrm{S} / \mathrm{N}$ ratio of $40 \%$ or less were considered positive while those with a $\mathrm{S} / \mathrm{N}$ ratio comprised between 40 and 50\% were considered doubtful, and those with a $\mathrm{S} / \mathrm{N}$ ratio higher than $50 \%$ were considered negative. This test has been used to give an indication of the presence or absence of anti-WNV antibodies in sera, but cross-reactions with other flaviviruses may occur (Beck et al., 2017).

\subsubsection{Microsphere immunoassay}

Flavivirus microsphere immunoassay (MIA) was performed on cELISA positive samples as described by Beck et al. (2015). Briefly, recombinant soluble ectodomain of WNV envelope (E) glycoprotein (WNV.sE) and the recombinant E domains III (rEDIIIs) of WNV, USUV and TBEV containing virus-specific epitopes were covalently bound to fluorescent beads following the protocol previously described in (Beck et al., 2015; Vanhomwegen et al., 2017). Reactivity against WNV.sE is indicative of the presence of anti-flavivirus antibodies (as with the IDVET cELISA), and WNV.EDIII, TBEV.EDIII and USUV.EDIII allows to distinguish between these flaviviruses. 
The cut-offs of WNV.sE, WNV.EDIII, and TBEV.EDIII antigens were found to be 17, 54 and 61, respectively, as described in (Beck et al., 2015). For USUV, due to no positive horse serum against this disease, the cut-off was determined from the mean of median of fluorescence (MFI) values of 66 negative horse sera plus 3 standard deviations of the mean. The 66 sera used to determine the cut-off were sampled in Poland (35 sera) and Ireland (31 sera) and were all found negative with the ID screen West Nile competition kit (IDVet). The MIA results were interpreted according to the following algorithm : (i) a serum was considered positive for WNV (or alternatively for USUV) if it reacted against WNV.sE and WNV.EDIII (of alternatively USUV.EDIII) (ii) In case of positive reactions with several rEDIIIs for viruses belonging to the Japanese encephalitis serocomplex (i.e. USUV and WNV) an animal was considered infected with a specific flavivirus if the corresponding bead coupled to rEDIII generated an MFI at least two-fold greater than that generated with the other beads. If a 2 fold difference could not be achieved, the animal was considered to be infected with WNV or USUV (iii) since TBEV belongs to another serocomplex, a serum was considered positive for TBEV when the TBEV.EDIII MFI was above the cut off (iiii) finally, a sample was considered positive for an undetermined flavivirus if it reacted with WNV.sE but not with any of the EDIIIs.

\subsubsection{Seroneutralization tests}

Flaviviruses identified by MIA and all undetermined ELISA-positive flavivirus samples were investigated using MNT against WNV and USUV.

Neutralizing antibody titers against WNV and USUV were determined by MNT on Vero cells in 96-well cell culture plates, following the protocol described in (Beck et al., 2015), using WNV strain IS-98-ST1 (Genbank ID AF481864.1, provided by P. Desprès, IPP) and USUV strain France 2018. The MNT results were interpreted according to the following rules: (i) A serum was considered positive if cells were protected at the 1:10 serum dilution for WNV and USUV. Owing cross-neutralization between flaviviruses especially in the same serocomplex, we identified the infecting flavivirus by considering the virus with the highest neutralization capacity, and with neutralization titers that differ by at least a four-fold factor (Beck et al 2015).

\section{Results}




\subsection{High-throughput screening of mosquito-borne viruses}

A total of 1,455 mosquitoes were analyzed. 670 mosquitos were collected from Mohamedia region, all belonging to Culex pipiens species, and 780 mosquitoes collected from regions of northern Morocco (Moulay Bouselham-Larache $(n=595)$ and Tangier $(n=190))$ belonging to Aedes detritus species $(\mathrm{n}=320)$, Aedes caspius $(\mathrm{n}=110)$, Anopheles maculipennis $(\mathrm{n}=5)$ and Culex pipiens species $(\mathrm{n}=160)$. Among tested pools $(146)$, one pool from Mohammedia area was positive for WNV (see table 1). On the other hand, all the pooled mosquitoes from Tanger and Moulay Bouselham regions were negative (Table 1).

\subsection{Real time RT-PCR}

The positive pool for WNV was confirmed by a real time RT-PCR targeting a different fragment of the WNV genome.

\subsection{Detection of anti-WNV antibodies in horses}

In order to determine the WNV seroprevalence in 92 horses, we used three techniques: cELISA which detects anti-flavivirus antibodies, the MIA test which allows to distinguish between the three flavivirus: WNV, USUV and TBEV, and the MNT which allows the confirmation of the presence of anti-WNV antibodies and anti-USUV antibodies.

The seroprevalence by cELISA was $33.7 \%$ (31/92). The MIA test showed that $25.0 \%(23 / 92)$ were positive for WNV, 2.1\% (2/92) were positive for USUV, 4.3\% (4/92) were positive for undetermined flavivirus and 2.1\% (2/92) were positive for both WNV and USUV (Table 2).

The MNT showed that 30.4\% (28/92) were positive for WNV with titers between 20 to superior to 320 . The results of the two methods were in accordance for the 23 MIA WNV positives. Conversely, 2 samples positive for USUV, 2 positives for both WNV and USUV and one for undetermined flavivirus by MIA were found WNV positive by MNT. All sera were negative for USUV in MNT (Table 3).

\section{Discussion}

This study reports, for the first time, the detection of WNV in Culex pipiens mosquitoes and high seroprevalence rate of WNV infection in horses from Morocco (30\% by MNT test). We used the new high-throughput screening method, which examines 38 arboviruses (94 different 
genotypes/serotypes) in a single experiment (Moutailler et al., 2019). In Morocco, WNV was isolated and sequenced only once during the epizootic of 2003. The viral isolation was performed from a cerebral biopsy of a dead horse (Schuffenecker et al., 2005). In our study, WNV-infected mosquitoes were only found in Mohammedia region and not in Moulay Bouselhame region, probably owing to the low number of specimens examined: 160 individuals in Moulay Bouselhame compared to 670 tested in Mohammedia region. We reported a low $C x$. pipiens infection rate $(0.15 \%(1 / 670)$, a result in agreement with other investigations (Engler et al., 2013): 1.2\% for Cx. pipiens in Tunisia (Monastiri et al., 2018), $0.56 \%$ for $C x$. perexiguus in Algeria (Benbetka et al., 2018), $0.24 \%$ for $C x$. interrogator and $0.28 \%$ for Cx. nigripalpus in Chiapas, México (Ulloa et al., 2009). Anti-flavivirus antibodies have been detected by cELISA in 34\% (31/92) of horse sera and 100\% (31/31) of cELISA positive sera were found reactive to the WNV.sE bead by MIA. These two independent methods corroborated the detection of anti-flavivirus antibodies in horses (Beck et al., 2015). To improve the specificity of flavivirus serological screening, flavivirus positive samples were tested by MIA using WNV.EDIII, USUV.EDIII and TBEV.EDIII antigens which contain virus-specific-epitopes (Beasley et al., 2004; Beck et al., 2015) and by MNT against WNV and USUV. A significant proportion of horses (23/28) were found to be WNV positive by the two technics. Two samples were found positive against USUV in MIA but positive for WNV in MNT. Such discordant results could originate from a lower specificity of the flavivirus EDIII MIA technique. The fact that these sera were tested by MIA with WNV and USUV nonstructural protein 1 (NS1) and were found positive for WNV (data not given) supports this hypothesis. We did not identify the flavivirus involved in 9.7\% (3/31) of horse infections evidenced by positive cELISA reactions. As already mentioned by several authors (Beck et al., 2015), WNV cELISA tests lack specificity in the diagnosis of WNV infection. Of 31 sera tested positive for anti-WNV IgG by ELISA, only 28 had specific neutralizing antibodies. Benjelloun and his collaborators studied seroprevalence of WNV in different regions of Morocco in 2011. They found a seroprevalence rate of WNV similar to our study $35 \%$ and $31 \%$ respectively by cELISA and MNT (Benjelloun et al., 2017). Another study carried out with 297 military working horses and 231 dogs in Morocco have described, respectively, a rate of $60 \%$ and $62 \%$ of seroprevalence by cELISA (Durand et al., 2016). This high rate of WNV seroprevalence has also been reported by other team in Tunises and Algeria (Ben Hassine et al., 2014; Lafri et al., 2017). USUV and WNV have been shown to co circulate and share the same vectors (Zannoli and Sambri, 2019); however, we did not detect USUV either in mosquitoes nor in horse sera, while USUV has been shown to circulate in 
Tunisia and in Morocco (Ayadi et al., 2019; Ben Hassine et al., 2014; Figuerola et al., 2009). For the sera found positive with the ELISA test and negative in WNV and USUV MNTs (3/31), such reactions could correspond to low WNV antibody responses under the detection MNT threshold or to animals infected with other flaviviruses (yellow fever virus, ...). Recently, cELISA positive and WNV MNT negative horses on French pacific islands turned out to be Dengue and Zika-infected. The serological results highlighted the importance of taking into account the risk of circulation of other arboviruses such as dengue, chikungunya and zika viruses, since the vector of these arboviruses, Ae. albopictus, was recently established in Morocco (Bennouna et al., 2017) and their ability to transmit these viruses efficiently has been experimentally proven (Amraoui et al., 2019).

Our results are in agreement with many arguments for active circulation of WNV in this area of Morocco that are: (i) high abundance of $C x$. pipiens mosquitoes in a region hosting migratory birds (Jourdain et al., 2007), and (ii) their ability to experimentally transmit WNV (Amraoui et al. 2012). The water reservoirs present in this area would constitute ideal ecological niches for repeated contacts between domestic or migratory birds and mosquitoes, thus allowing the amplification of the virus in an enzootic cycle (Zeller and Murgue, 2001). WNV has been responsible for sporadic outbreaks of disease in countries around the Mediterranean sea since the 1960 (Hubálek and Halouzka, 1999). These have involved infections in humans and/or horses (Zeller et al., 2004). All outbreaks were reported between July and September. The principal vector of WNV in Europe and USA is Culex pipiens (Esteves et al., 2005; Kilpatrick et al., 2005). These countries have favorable conditions for maintaining the WNV transmission cycle such as environmental factors and climatic conditions (Rogers and Randolph, 2006). These conditions support virus circulation, and when the density of vector mosquitoes is enhanced and sensitive hosts are available, outbreaks are observed. The high prevalence of antibodies among horses also suggest that substantial circulation of the virus may have occurred during the previous seasons. The observed titer of the positive sera is probably due to re-infections during the previous 2010 outbreak or a prolonged and repeated exposure to viruses in endemics areas. These results suggest that WNV was present in Morocco in 2018 without resulting in disease outbreaks among humans or horses, as opposed to in 1996, 2003 and 2010, when cases did occur (El Harrack et al., 1997; El Rhaffouli et al., 2012; Schuffenecker et al., 2005). Absence of outbreaks despite the circulation of the virus could be explained by the acquisition of a 
protective immunity after the first infection by humans and horses and, possibly by the lack of entomological virus surveillance and asymptomatic underreported cases.

331 Our results strongly suggest that WNV remains silent and spillover events to humans occurs 332 only under favorable ecological conditions. Therefore, understanding ecological factors and environmental conditions leading to WNV outbreak is of major importance. Persistence of WNV in over wintering Cx. pipiens is an important mechanism in the maintenance of this arbovirus (Nasci et al., 2001). Thus, WNV is likely to cause future sporadic and foreseeable outbreaks not only in Morocco but along the migratory flyways of birds between Africa and Europe. Virus circulation becomes permanent and is probably maintained by mosquito vector movements and reintroduction of migratory birds.

This study brings important data about an active WNV circulation in mosquitoes in Morocco. It is suggested that public health authorities should implement WNV surveillance activities and setting up an entomological surveillance as an early alert system around the Mediterranean Basin to prevent future outbreaks is highly needed.

\section{Acknowledgements}

This study was funded by Institut Pasteur of Morocco and Pasteur Institute in Paris. We thank Mr. Abbani Labaoui for his help in the field work and also the managers of the equestrian clubs for the blood samples from horses.

\section{Author contributions}

Conceptualization: Anna-Bella Failloux, M'hammed Sarih

Formal analysis: Najlaa Assaid.

Investigation: Najlaa Assaid, Laurence Mousson, sara Moutailler, Soukaina Arich, Khadija Akharid, Cécile Beck, Sylvie lecollinet,

Methodology: Anna-Bella Failloux, Laurence Mousson, sara Moutailler, Soukaina Arich, Khadija Akharid, Cécile Beck, Sylvie Lecollinet, Najlaa Assaid, M’hammed Sarih

Supervision: Anna-Bella Failloux, M'hammed Sarih, Sylvie lecollinet

Validation: Anna-Bella Failloux, M’hammed Sarih, Sylvie lecollinet

Writing-original draft: Najlaa Assaid, M'hammed Sarih 
Amraoui, F., Ayed, W.B., Madec, Y., Faraj, C., Himmi, O., Btissam, A., Sarih, M., Failloux, A.-B., 2019. Potential of Aedes albopictus to cause the emergence of arboviruses in Morocco. PLoS Negl. Trop. Dis. 13, e0006997.

Amraoui, F., Krida, G., Bouattour, A., Rhim, A., Daaboub, J., Harrat, Z., Boubidi, S.-C., Tijane, M., Sarih, M., Failloux, A.-B., 2012a. Culex pipiens, an experimental efficient vector of West Nile and Rift Valley fever viruses in the Maghreb region. PloS One 7, e36757.

Amraoui, F., Tijane, M., Sarih, M., Failloux, A.-B., 2012b. Molecular evidence of Culex pipiens form molestus and hybrids pipiens/molestus in Morocco, North Africa. Parasit. Vectors 5, 83.

Ayadi, T., Hammouda, A., Beck, C., Boulinier, T., Lecollinet, S., Selmi, S., 2019. Flaviviruses in migratory passerines during spring stopover in a desert oasis. Zoonoses Public Health.

Banet-Noach, Ca., Simanov, L., Malkinson, M., 2003. Direct (non-vector) transmission of West Nile virus in geese. Avian Pathol. 32, 489-494.

Beasley, D.W., Holbrook, M.R., Da Rosa, A.P.T., Coffey, L., Carrara, A.-S., Phillippi-Falkenstein, K., Bohm, R.P., Ratterree, M.S., Lillibridge, K.M., Ludwig, G.V., 2004. Use of a recombinant envelope protein subunit antigen for specific serological diagnosis of West Nile virus infection. J. Clin. Microbiol. 42, 2759-2765.

Beck, C., Desprès, P., Paulous, S., Vanhomwegen, J., Lowenski, S., Nowotny, N., Durand, B., Garnier, A., Blaise-Boisseau, S., Guitton, E., Yamanaka, T., Zientara, S., Lecollinet, S., 2015. A HighPerformance Multiplex Immunoassay for Serodiagnosis of Flavivirus-Associated Neurological Diseases in Horses. BioMed Res. Int. 2015. https://doi.org/10.1155/2015/678084

Beck, C., Lowenski, S., Durand, B., Bahuon, C., Zientara, S., Lecollinet, S., 2017. Improved reliability of serological tools for the diagnosis of West Nile fever in horses within Europe. PLoS Negl. Trop. Dis. 11, e0005936.

Ben Hassine, T., De Massis, F., Calistri, P., Savini, G., BelHaj Mohamed, B., Ranen, A., Di Gennaro, A., Sghaier, S., Hammami, S., 2014. First detection of co-circulation of West Nile and Usutu viruses in equids in the South-west of Tunisia. Transbound. Emerg. Dis. 61, 385-389.

Benbetka, S., Hachid, A., Benallal, K.E., Benbetka, C., Khaldi, A., Bitam, I., Harrat, Z., 2018. First field evidence infection of Culex perexiguus by West Nile virus in Sahara Oasis of Algeria. J. Vector Borne Dis. 55, 305.

Benjelloun, A., El Harrak, M., Belkadi, B., 2016. West Nile disease epidemiology in North-West Africa: bibliographical review. Transbound. Emerg. Dis. 63, e153-e159.

Benjelloun, A., El Harrak, M., Calistri, P., Loutfi, C., Kabbaj, H., Conte, A., Ippoliti, C., Danzetta, M.L., Belkadi, B., 2017. Seroprevalence of West Nile virus in horses in different Moroccan regions. Vet. Med. Sci. 3, 198-207.

Bennouna, A., Balenghien, T., El Rhaffouli, H., Schaffner, F., Garros, C., Gardes, L., Lhor, Y., Hammoumi, S., Chlyeh, G., Fassi Fihri, O., 2017. First record of Stegomyia albopicta (= Aedes albopictus) in Morocco: a major threat to public health in North Africa? Med. Vet. Entomol. 31, 102-106.

Bowen, R.A., Nemeth, N.M., 2007. Experimental infections with West Nile virus. Curr. Opin. Infect. Dis. 20, 293-297.

Brunhes, J., Rhaim, A., Geoffroy, B., Angel, G., Hervy, J.-P., 2000. Les moustiques de I'Afrique méditerranéenne: logiciel $d$ 'identification et d'enseignement.

Calzolari, M., Gaibani, P., Bellini, R., Defilippo, F., Pierro, A., Albieri, A., Maioli, G., Luppi, A., Rossini, G., Balzani, A., 2012. Mosquito, bird and human surveillance of West Nile and Usutu viruses in Emilia-Romagna Region (Italy) in 2010. PLoS One 7, e38058.

Chancey, C., Grinev, A., Volkova, E., Rios, M., 2015. The global ecology and epidemiology of West Nile virus. BioMed Res. Int. 2015.

Charrel, R.N., Brault, A.C., Gallian, P., Lemasson, J.-J., Murgue, B., Murri, S., Pastorino, B., Zeller, H., De Chesse, R., De Micco, P., 2003. Evolutionary relationship between Old World West Nile 
virus strains: evidence for viral gene flow between Africa, the Middle East, and Europe. Virology 315, 381-388.

Durand, B., Haskouri, H., Lowenski, S., Vachiéry, N., Beck, C., Lecollinet, S., 2016. Seroprevalence of West Nile and Usutu viruses in military working horses and dogs, Morocco, 2012: dog as an alternative WNV sentinel species? Epidemiol. Infect. 144, 1857-1864.

El Harrack, M., Le Guenno, B., Gounon, P., 1997. Isolement du virus West Nile au Maroc. Virologie 1, 248-9.

El Rhaffouli, H., El Harrak, M., Lotfi, C., El Boukhrissi, F., Bajjou, T., Laraqui, A., Hilali, F., Kenfaoui, M., Lahlou-Amine, I., 2012. Serologic evidence of West Nile virus infection among humans, Morocco. Emerg. Infect. Dis. 18, 880.

El Rhaffouli, H., Lahlou-Amine, I., Loutfi, C., Laraqui, A., Bajjou, T., Fassi-Fihri, O., El Harrak, M., 2013. Serological evidence of West Nile Virus infection among humans in the southern Provinces of Morocco. J. Infect. Dev. Ctries. 7, 999-1002.

Engler, O., Savini, G., Papa, A., Figuerola, J., Groschup, M.H., Kampen, H., Medlock, J., Vaux, A., Wilson, A.J., Werner, D., 2013. European surveillance for West Nile virus in mosquito populations. Int. J. Environ. Res. Public. Health 10, 4869-4895.

Esteves, A., Almeida, A.P.G., Galão, R.P., Parreira, R., Piedade, J., Rodrigues, J.C., Sousa, C.A., Novo, M.T., 2005. West Nile virus in southern Portugal, 2004. Vector-Borne Zoonotic Dis. 5, 410413.

Figuerola, J., Baouab, R.E., Soriguer, R., Fassi-Fihri, O., Llorente, F., Jímenez-Clavero, M.A., 2009. West Nile virus antibodies in wild birds, Morocco, 2008. Emerg. Infect. Dis. 15, 1651.

Fonseca, D.M., Keyghobadi, N., Malcolm, C.A., Mehmet, C., Schaffner, F., Mogi, M., Fleischer, R.C., Wilkerson, R.C., 2004. Emerging vectors in the Culex pipiens complex. Science 303, 15351538.

Gomes, B., Sousa, C.A., Novo, M.T., Freitas, F.B., Alves, R., Côrte-Real, A.R., Salgueiro, P., Donnelly, M.J., Almeida, A.P., Pinto, J., 2009. Asymmetric introgression between sympatric molestus and pipiens forms of Culex pipiens (Diptera: Culicidae) in the Comporta region, Portugal. BMC Evol. Biol. 9, 262.

Harbach, R.E., 2012. Culex pipiens: species versus species complex-taxonomic history and perspective. J. Am. Mosq. Control Assoc. 28, 10-23.

Hayes, C.G., 2001. West Nile virus: Uganda, 1937, to New York City, 1999. Ann. N. Y. Acad. Sci. 951, 25-37.

Hubálek, Z., Halouzka, J., 1999. West Nile fever-a reemerging mosquito-borne viral disease in Europe. Emerg. Infect. Dis. 5, 643.

Johnson, N., Fernández de Marco, M., Giovannini, A., Ippoliti, C., Danzetta, M., Svartz, G., Erster, O., Groschup, M., Ziegler, U., Mirazimi, A., 2018. Emerging mosquito-borne threats and the response from European and Eastern Mediterranean Countries. Int. J. Environ. Res. Public. Health 15, 2775.

Jourdain, E., Schuffenecker, I., Korimbocus, J., Reynard, S., Murri, S., Kayser, Y., Gauthier-Clerc, M., Sabatier, P., Zeller, H.G., 2007. West Nile virus in wild resident birds, Southern France, 2004. Vector-Borne Zoonotic Dis. 7, 448-452.

Kilpatrick, A.M., Kramer, L.D., Campbell, S.R., Alleyne, E.O., Dobson, A.P., Daszak, P., 2005. West Nile virus risk assessment and the bridge vector paradigm. Emerg. Infect. Dis. 11, 425.

Komar, N., Langevin, S., Hinten, S., Nemeth, N., Edwards, E., Hettler, D., Davis, B., Bowen, R., Bunning, M., 2003. Experimental infection of North American birds with the New York 1999 strain of West Nile virus. Emerg. Infect. Dis. 9, 311.

Krida, G., Rhim, A., Daaboub, J., Failloux, A.-B., Bouattour, A., 2015. New evidence for the potential role of Culex pipiens mosquitoes in the transmission cycle of West Nile virus in Tunisia. Med. Vet. Entomol. 29, 124-128.

Lafri, I., Prat, C.M., Bitam, I., Gravier, P., Besbaci, M., Zeroual, F., Ben-Mahdi, M.H., Davoust, B., Leparc-Goffart, I., 2017. Seroprevalence of West Nile virus antibodies in equids in the North- 
East of Algeria and detection of virus circulation in 2014. Comp. Immunol. Microbiol. Infect. Dis. 50, 8-12.

Lecollinet, S., Pronost, S., Coulpier, M., Beck, C., Gonzalez, G., Leblond, A., Tritz, P., 2020. Viral Equine Encephalitis, a Growing Threat to the Horse Population in Europe? Viruses 12, 23. https://doi.org/10.3390/v12010023

Linke, S., Ellerbrok, H., Niedrig, M., Nitsche, A., Pauli, G., 2007. Detection of West Nile virus lineages 1 and 2 by real-time PCR. J. Virol. Methods 146, 355-358.

Michelet, L., Delannoy, S., Devillers, E., Umhang, G., Aspan, A., Juremalm, M., Chirico, J., van der Wal, F.J., Sprong, H., Boye Pihl, T.P., 2014. High-throughput screening of tick-borne pathogens in Europe. Front. Cell. Infect. Microbiol. 4, 103.

Monastiri, A., Mechri, B., Vázquez-González, A., Ar Gouilh, M., Chakroun, M., Loussaief, C., Mastouri, M., Dimassi, N., Boughzala, L., Aouni, M., 2018. A four-year survey (2011-2014) of West Nile virus infection in humans, mosquitoes and birds, including the 2012 meningoencephalitis outbreak in Tunisia. Emerg. Microbes Infect. 7, 1-10.

Moutailler, S., Yousfi, L., Mousson, L., Devillers, E., Vazeille, M., Vega-Rúa, A., Perrin, Y., Jourdain, F., Chandre, F., Cannet, A., 2019. A new high-throughput tool to screen mosquito-borne viruses in Zika virus endemic/epidemic areas. Viruses 11, 904.

Murgue, B., Murri, S., Triki, H., Deubel, V., Zeller, H.G., 2001. West Nile in the Mediterranean Basin: 1950-2000. Ann. N. Y. Acad. Sci. 951, 117-126.

Nasci, R.S., Savage, H.M., White, D.J., Miller, J.R., Cropp, B.C., Godsey, M.S., Kerst, A.J., Bennett, P., Gottfried, K., Lanciotti, R.S., 2001. West Nile virus in overwintering Culex mosquitoes, New York City, 2000. Emerg. Infect. Dis. 7, 742.

Nash, D., Mostashari, F., Fine, A., Miller, J., O'Leary, D., Murray, K., Huang, A., Rosenberg, A., Greenberg, A., Sherman, M., 2001. The outbreak of West Nile virus infection in the New York City area in 1999. N. Engl. J. Med. 344, 1807-1814.

Nielsen, E.M., Andersen, M.T., 2003. Detection and characterization of verocytotoxin-producing Escherichia coli by automated 5' nuclease PCR assay. J. Clin. Microbiol. 41, 2884-2893.

Papa, A., 2019. Emerging arboviruses of medical importance in the Mediterranean region. J. Clin. Virol. 115, 5-10.

Rogers, D.J., Randolph, S.E., 2006. Climate change and vector-borne diseases. Adv. Parasitol. 62, 345381.

Romo, H., Papa, A., Kading, R., Clark, R., Delorey, M., Brault, A.C., 2018. Comparative vector competence of North American Culex pipiens and Culex quinquefasciatus for African and European lineage 2 West Nile viruses. Am. J. Trop. Med. Hyg. 98, 1863-1869.

Schuffenecker, I., Peyrefitte, C.N., El Harrak, M., Murri, S., Leblond, A., Zeller, H.G., 2005. West Nile virus in Morocco, 2003. Emerg. Infect. Dis. 11, 306.

Smithburn, K.C., 1942. Differentiation of the West Nile Virus from the Viruses of St. Louis and Japanese B Encephalitis. J. Immunol. 43, 25-31.

Sule, W.F., Oluwayelu, D.O., Hernández-Triana, L.M., Fooks, A.R., Venter, M., Johnson, N., 2018. Epidemiology and ecology of West Nile virus in sub-Saharan Africa. Parasit. Vectors 11, 414.

Sutherst, R.W., 2004. Global change and human vulnerability to vector-borne diseases. Clin. Microbiol. Rev. 17, 136-173.

Tber Abdelhaq, A., 1996. West Nile fever in horses in Morocco. Bull. Off. Int. Epizoot. 108, 867-869.

Ulloa, A., Ferguson, H.H., Méndez-Sánchez, J.D., Danis-Lozano, R., Casas-Martínez, M., Bond, J.G., García-Zebadúa, J.C., Orozco-Bonilla, A., Juárez-Ordaz, J.A., Farfan-Ale, J.A., 2009. West Nile virus activity in mosquitoes and domestic animals in Chiapas, México. Vector-Borne Zoonotic Dis. 9, 555-560.

Vanhomwegen, J., Beck, C., Despres, P., Figuerola, A., García, R., Lecollinet, S., López-Roig, M., Manuguerra, J.-C., Serra-Cobo, J., 2017. Circulation of Zoonotic Arboviruses in Equine Populations of Mallorca Island (Spain). Vector-Borne Zoonotic Dis. 17, 340-346.

Weaver, S.C., Charlier, C., Vasilakis, N., Lecuit, M., 2018. Zika, chikungunya, and other emerging vector-borne viral diseases. Annu. Rev. Med. 69, 395-408. 
513 Weaver, S.C., Reisen, W.K., 2010. Present and future arboviral threats. Antiviral Res. 85, 328-345.

514 Zannoli, S., Sambri, V., 2019. West Nile virus and Usutu virus co-circulation in Europe: epidemiology and implications. Microorganisms 7, 184.

Zeller, H., Zientara, S., Hars, J., Languille, J., Mailles, A., Tolou, H., Paty, M.-C., Schaffner, F., Armengaud, A., Gaillan, P., 2004. West Nile outbreak in horses in southern France: September 2004. Eurosurveillance Wkly. 8, 07.

Zeller, H.G., Murgue, B., 2001. The role of migrating birds in the West Nile virus epidemiology. Med. Mal. Infect. 31, 168S-174S. 
Table 1: Mosquito species, number of mosquitoes collected and virus detected by high-throuput chip based on the BioMark Dynamic arrays system.

\begin{tabular}{|c|c|c|c|c|c|c|c|}
\hline Collection Site & « GPS » coordinates & Biotope & $\begin{array}{l}\text { Mosquito } \\
\text { Species }\end{array}$ & $\begin{array}{c}\text { Number of } \\
\text { mosquitoes } \\
\text { screened }\end{array}$ & $\begin{array}{c}\text { Number of } \\
\text { pools }\end{array}$ & $\begin{array}{c}\text { Virus } \\
\text { Detected } \\
\text { through } \\
\text { Microfluidic } \\
\text { System }\end{array}$ & $\begin{array}{c}\text { Type of } \\
\text { confirmation } \\
\text { Performed }\end{array}$ \\
\hline Mohammedia & $33^{\circ} 38^{\prime} 22.4 \mathrm{~N} 7^{\circ} 26^{\prime} 08.8 \mathrm{~W}$ & $\begin{array}{l}\text { Peri - } \\
\text { urban }\end{array}$ & Culex pipiens & 670 & 67 & WNV* & $\begin{array}{l}\text { WNV confirmed } \\
\text { by Real time RT- } \\
\text { PCR }\end{array}$ \\
\hline Tanger & $35^{\circ} 46^{\prime} 44.3 \mathrm{~N} 5^{\circ} 50^{\prime} 50.1 \mathrm{~W}$ & Urban & Culex pipiens & 190 & 19 & - & - \\
\hline Moulay bouselham & $34^{\circ} 52^{\prime} 28.7^{\prime \prime} 6^{\circ} 17^{\prime} 14.5^{\prime \prime} \mathrm{W}$ & Rural & $\begin{array}{c}\text { anoh detritus, } \\
\text { Aedes caspius, } \\
\text { culex pipiens, } \\
\text { Anophele } \\
\text { maculipennis }\end{array}$ & $\begin{array}{c}320 \\
110 \\
160 \\
5\end{array}$ & $\begin{array}{r}32 \\
11 \\
16 \\
1\end{array}$ & - & - \\
\hline Total & & & & 1455 & 146 & & \\
\hline
\end{tabular}

WNV., West Nile virus; CHIKV., Chikungunya virus. (-) no virus detected and no confirmation performed. *WNV detected in one pool of Cx.pipiens. 
Table 2: cELISA flavivirus results and WNV, USUV and TBEV results by MIA

\begin{tabular}{|ccccccccc|}
\hline Number of samples & \multicolumn{3}{c|}{ cELISA } & \multicolumn{3}{c|}{ MIA confirmation of positive cELISA results } \\
\hline Number of horses sampled & negative & Doubtful & Positive & WNV & USUV & TBEV & Flavivirus & WNV or USUV \\
\hline 92 & 61 & 0 & $31(33.7 \%)^{*}$ & $23(25 \%)^{*}$ & $2(2.1 \%)^{*}$ & 0 & $4(4.3 \%)^{*}$ & $2(2.1 \%)^{*}$ \\
\hline
\end{tabular}

* The percentage was based on total sample numbers (assuming all cELISA negative would also be negative by MIA) 
Table 3: MNT confirmation of positive cELISA against WNV and USUV

\begin{tabular}{|ccccccccccc|}
\hline Number of samples & USUV & undetermined flavivirus & WNV & \multicolumn{5}{c|}{ Distribution of WNV positive samples by titer (\%) } \\
\hline 31 & 0 & 3 & $28(30.4 \%)$ & $1: 20$ & $1: 40$ & $1: 80$ & $1: 160$ & $1: 320$ & $>1: 320$ \\
\hline & & & & $3(3.3 \%)^{*}$ & $2(2,3 \%)^{*}$ & $1(1 \%)^{*}$ & $(11,9 \%)^{*}$ & $4(4.3 \%)^{*}$ & $(7.6 \%)^{*}$ \\
\hline
\end{tabular}

* The percentage was based on total sample numbers (assuming all cELISA negative would also be negative by MNT) 